\title{
Trade-offs among forest value components in community forests of southwestern Amazonia
}

\author{
Christopher Baraloto $^{1,2}{ }^{\text {, Paula Alverga }}{ }^{3}$, Sufer Baéz Quispe ${ }^{4}$ Grenville Barnes $^{5}$, Nino Bejar Chura ${ }^{4}$, Izaias Brasil da Silva ${ }^{3}$, Wendeson \\ Castro $^{3}$, Harrison da Souza ${ }^{6}$, Iracema de Souza Moll ${ }^{3}$, Jim del Alcazar Chilo ${ }^{4}$, Hugo Duenas Linares ${ }^{4}$, Jorge Garate Quispe ${ }^{4}$, Dean \\ Kenji $^{6}$, Herison Medeiros ${ }^{3}$, Skya Murphy ${ }^{2}$, Cara A. Rockwell ${ }^{5}$, Alexander Shenkin ${ }^{2,5}$, Marcos Silveira ${ }^{3}$, Jane Southworth ${ }^{7}$, Guido \\ Vasquez ${ }^{6}$ and Stephen Perz ${ }^{8}$
}

\begin{abstract}
Contemporary conservation interventions must balance potential trade-offs between multiple ecosystem services. In tropical forests, much attention has focused on the extent to which carbon-based conservation provided by REDD+ policies can also mitigate biodiversity conservation. In the nearly one-third of tropical forests that are community owned or managed, conservation strategies must also balance the multiple uses of forest products that support local livelihoods. Although much discussion has focused on policy options, little empirical evidence exists to evaluate the potential for trade-offs among different tropical forest value components. We assessed multiple components of forest value, including tree diversity, carbon stocks, and both timber and nontimber forest product resources, in forest communities across the trinational frontier of Brazil, Peru, and Bolivia. We installed 69 0.5-ha vegetation plots in local communities, and we characterized 15 components of forest value for each plot. Principal components analyses revealed two major axes of forest value, the first of which defined a trade-off between diversity of woody plant communities (taxonomic and functional) versus aboveground biomass and standing timber volume. The second axis described abundance of commercial species, with strong positive loadings for density of timber and nontimber forest products, including Brazil nut (Bertholletia excelsa) and copaiba oil (Copaifera spp.). The observed trade-off between different components of forest value suggests a potential for management conflicts prioritizing biodiversity conservation versus carbon stocks in the region. We discuss the potential for integrative indices of forest value for tropical forest conservation.
\end{abstract}

Key Words: açai; biodiversity conservation; Brazil nut; carbon stocks; livelihood; NTFP; REDD; rubber; timber; tropical rainforest

\section{INTRODUCTION}

Contemporary conservation interventions strive to meet multiple goals, including the maintenance of biodiversity and ecosystem services such as biogeochemical cycles, as well as the alleviation of poverty (Sunderlin et al. 2005, Hirsch et al. 2011). Since the 1992 United Nations Conference on Environment and Development in Rio de Janeiro, Brazil, international policy efforts have sought to reconcile these environmental and socioeconomic priorities (Balmford et al. 2002). For example, protected areas designed for biodiversity conservation often aim to provide other public services such as local sustainable use of natural resources (Schwartzman et al. 2000), stability of regional climates (SoaresFilho et al. 2006), reduced air pollution levels, and watershed maintenance (Parviainen and Frank 2003, Chisholm 2010). Similarly, the development of Reduced Emissions from Deforestation and Forest Degradation (REDD+) initiatives, which protect areas of high carbon stocks via regulatory enforcement and incentive-based mechanisms such as payments for ecosystem services (Angelsen and Brockhaus 2009, Sunderlin and Sills 2012, Duchelle et al. 2014), calls for "cobenefits," including biodiversity conservation and the enhancement of rural livelihoods (UNFCC 2011, Phelps et al. 2012a, Strassburg et al. 2012). Still, policy options seeking to minimize environmental and economic trade-offs among conservation goals are currently confronted with insufficient empirical data to evaluate potential trade-offs among different components of forest value (Paoli et al. 2010, Hirsch et al. 2011, Phelps et al. 2012b).
Global analyses of ecosystem services have revealed geographic overlaps among areas with both high carbon stocks and high biodiversity (Venter et al. 2009, Strassburg et al. 2010). These analyses point to the potential for cobenefits of REDD+ policies to mitigate species extinctions (Phelps et al. 2012b, Strassburg et al. 2012). Nevertheless, at the regional scale, the correspondence of carbon stocks and biodiversity may not be as strong (Paoli et al. 2010, Thomas et al. 2013). If other ecosystem services do not exhibit a strong spatial correspondence with biodiversity, implementation of policies focusing on a specific ecosystem service such as REDD+ and carbon stocks runs significant risks of the displacement of resource exploitation into areas with low carbon stocks but high biodiversity (Paoli et al. 2010, Gardner et al. 2012, Phelps et al. 2012b, Siikamäki and Newbold 2012, Thomas et al. 2013).

Tropical forests represent priority areas where REDD+ interventions may have significant cobenefits for biodiversity conservation, because they harbor more than half of the world's threatened species (Le Saout et al. 2013) and represent a major source of global greenhouse gas emissions (van der Werf et al. 2009). In the nearly one-third of tropical forests that are community owned or managed (Sunderlin et al. 2008), conservation strategies must also balance the multiple uses of forest products that support local livelihoods (Duchelle et al. 2012). Recognition of the economic as well as ecological value of standing forest is of course not new. Indeed, initial approaches to

${ }^{1}$ INRA, UMR Ecologie des Forêts de Guyane, French Guiana, ${ }^{2}$ Department of Biology, University of Florida, USA, ${ }^{3}$ Universidade Federal do Acre, Brazil, ${ }^{4}$ Herbario Alwyn Gentry, Universidad Nacional Amazónica de Madre de Dios, Peru, ${ }^{5}$ School of Forest Resources and Conservation, University of Florida, USA, ${ }^{6}$ Universidad Amazónica de Pando, Bolivia, ${ }^{7}$ Department of Geography and Land Use and Environmental Change Institute, University of Florida, USA, ${ }^{8}$ Department of Sociology and Criminology \& Law, University of Florida, USA 
forest valuation emerged before the development of carbon markets, arguing that standing forests had significant economic value in support of local livelihoods before accounting for carbon stocks or other ecosystem services (Peters et al. 1989, Godoy et al. 2000). The extent to which geographic targeting for carbon emission reductions may limit the development of resource extraction for timber and nontimber forest products (NTFPs) must therefore be considered (UNFCC 2011, Phelps et al. 2012a). Furthermore, if timber stocks overlap geographically with areas rich in NTFPs, then conflicts of use may ensue if policies prioritize one over the other. The same applies to policies targeting carbon emissions or biodiversity conservation (Guariguata et al. 2010, Shanley et al. 2012, Herrero-Jáuregui et al. 2013).

The mitigation of conservation trade-offs is further complicated by the choice of appropriate metrics representing biodiversity, in at least three ways. First, different focal species groups such as plants, insects, and mammals may have different biogeographic distributions and may respond differently to disturbances (Gardner et al. 2008). Second, biodiversity priorities may include not only total site diversity, but also the presence of threatened or endemic species (Strassburg et al. 2010, LeSaout et al. 2013). Third, different diversity metrics target different levels of biological organization and may provide contrasting results. Recent analyses have shown that traditional metrics of taxonomic diversity are not always congruent with either phylogenetic diversity, which may capture the potential for adaptation (Tucker and Cadotte 2013), or functional diversity, which may help predict the resilience of communities to global change (Lavorel 2013). In particular, functional diversity has been directly linked to important ecological processes tied to economically important ecosystem services (de Bello et al. 2010, Mouillot et al. 2011, Lavorel 2013) and has been shown to respond differently to disturbance than taxonomic diversity (Baraloto et al. 2012a).

Given the numerous and diverse stakeholders in tropical forest regions, there exists an urgent need for comprehensive metrics of tropical forest value. Such metrics must encompass not only carbon stocks and other ecosystem services, but also multiple aspects of biodiversity, as well as timber and NTFPs essential to rural livelihoods (UNFCC 2011, Phelps et al. 2012a, Ninan and Inoue 2013).

Recent approaches have been developed to estimate some components of forest value using pre-existing data sources that rely on information about forest structure. Such efforts typically highlight estimation of timber stocks and aboveground biomass as derived from remote sensing techniques (Asner et al. 2010) or coarse resolution forestry inventory data (Ahmed and Ewers 2012). However, even for these relatively straightforward components of forest value related to forest structure, substantial uncertainty remains about different forest types with varying degrees of degradation (Sasaki and Putz 2009). As a result, empirical approaches using targeted field data via forest inventories are still needed to assess these and other components of forest value, and to serve as eventual calibration data as remote sensing techniques are developed (Hosonuma et al. 2012).

The southwestern Amazon represents a compelling example for more inclusive studies of forest value. The region is recognized for high biodiversity and particularly the presence of endemic species (ter Steege et al. 2013). Communities in the region practice multiple use forest management, which includes harvesting of both timber, particularly cumaru (Dipteryx spp.), cumaru cetim (Apuleia leiocarpa), ipe (Tabebuia spp.), and cedro (Cedrela spp.), as well as collection of numerous NTFPs, including Brazil nuts (Bertholletia excelsa), rubber (Hevea brasiliensis), sap resins and oils (Copaifera spp., Myroxylon balsamum, Hymenaea courbaril), and palm fruits for food (Euterpe precatoria), in addition to subsistence hunting and materials consumption (Vadjunec and Rocheleau 2009, Gomes et al. 2012, Duchelle et al. 2012). At the same time, there are incipient programs in place for environmental service payments related to forest carbon in the region, such as Acre's System of Incentives for Environmental Services, which was passed into state law in 2010 (Duchelle et al. 2014), along with multiple pilot REDD+ projects in Madre de Dios (Hajek et al. 2011). Despite these numerous sources of forest value, the region is also threatened by agricultural expansion and forest degradation accompanying the recent paving of the Inter-Oceanic Highway (Southworth et al. 2011, Perz et al.2013), and by the acceleration of illegal gold mining (Asner et al. 2013).

We derive empirical estimates of forest value from a network of vegetation plots across the trinational frontier in the southwestern Amazon where Bolivia, Brazil, and Peru meet. We consider a suite of metrics of forest value including carbon in forest biomass, taxonomic as well as functional plant diversity, and availability of both timber and NTFPs. We then ask how these different components of forest value are correlated to test for potential conservation trade-offs in policies that focus on one or another component of forest value. In particular, we examine (i) the frequency of trade-offs in geographic targeting between carbon emissions reductions versus different aspects of biodiversity conservation, and (ii) the potential for use of trade-offs resulting from overlap in priority sites for carbon stocks or biodiversity conservation versus exploitable resources supporting local livelihoods. We discuss our results in light of the pressing conservation issues of this dynamic and understudied region.

\section{METHODS}

\section{Study sites}

This study was conducted as part of a larger project on socialecological resilience in the MAP trinational frontier region of Acre, Brazil, Madre de Dios, Peru, and Pando, Bolivia (see Perz et al. 2013). We worked with a series of forest resident communities that were selected to represent geographic variability and the major land tenure classes identified along the Inter-Oceanic Highway that provides access across the region (Fig. 1). In each community, we worked with community leaders to secure their consent to host the study and to identify representative landholdings of the area circumscribed by the community. Our objective was to focus on the most representative terra firme forests, so we avoided seasonally inundated forests and areas that were not representative of the local landholding because of extreme human impacts (or lack thereof).

\section{Sampling methods}

We sampled 69 sites using a modification of the Phillips et al. (2003, 2006) modified Gentry plot method (Baraloto et al. 2011), which has been demonstrated to be effective in measuring both aboveground biomass and floristic composition in Neotropical forests (Baraloto et al. 2013). The core design of the plot is 10 subplots of $2 \times 50 \mathrm{~m}$ (totaling $0.1 \mathrm{ha}$ ), arranged within a $100 \times 190$ $\mathrm{m}$ sampling grid so as to systematically sample 1.9 ha of forest, with subplots oriented in alternative perpendicular directions to a 
Table 1. Forest value components defined in this study, including a code to abbreviations used in figures, their units, range, and description.

\begin{tabular}{|c|c|c|c|c|}
\hline Attribute & Abbrev & units & Mean (Range) & Description \\
\hline Tree genus diversity & TreeDiv & & $\begin{array}{c}0.95 \\
(0.830 .98)\end{array}$ & $\begin{array}{l}\text { Simpson index, i.e., probability of drawing a pair of individuals from } \\
\text { two different genera }\end{array}$ \\
\hline $\begin{array}{l}\text { Tree functional } \\
\text { diversity }\end{array}$ & FunDiv & & $\begin{array}{c}0.92 \\
(0.750 .99)\end{array}$ & $\begin{array}{l}\text { Rao's quadratic entropy (Pavoine and Bonsall 2011), integrating } \\
\text { differences among genera in leaf and wood functional trait values with } \\
\text { relative abundances of genera in each site }\end{array}$ \\
\hline $\begin{array}{l}\text { Aboveground } \\
\text { biomass }\end{array}$ & AGB10 & $\mathrm{Mg} \mathrm{ha}^{-1}$ & $\begin{array}{c}191 \\
(40584)\end{array}$ & $\begin{array}{l}\text { Biomass of stems with diameter greater than } 10 \mathrm{~cm} \text {, calculated using } \\
\text { the allometry of Chave et al. }(2005)\end{array}$ \\
\hline Small stem biomass & AGBsm & $\mathrm{Mg} \mathrm{ha}^{-1}$ & $\begin{array}{c}7.4 \\
(2.710 .7)\end{array}$ & $\begin{array}{l}\text { Biomass of stems with diameter less than } 10 \mathrm{~cm} \text { (and greater than } 2.5 \\
\mathrm{~cm} \text { ), calculated using the allometry of Hughes et al. (1999) }\end{array}$ \\
\hline Timber volume & Timber & $\mathrm{m}^{3} \mathrm{ha}^{-1}$ & $\begin{array}{c}57 \\
(0386)\end{array}$ & $\begin{array}{l}\text { Total commercial volume of } 28 \text { genera, calculated using the allometry } \\
\text { of Nogueira et al. (2008) }\end{array}$ \\
\hline Future crop trees & TimFCT & stems ha ${ }^{-1}$ & $\begin{array}{c}63 \\
(8270)\end{array}$ & $\begin{array}{l}\text { Total density of future timber crop trees, defined as having DBH } \\
\text { between } 20 \text { and } 45 \mathrm{~cm} \text {, of } 28 \text { commercial timber genera }\end{array}$ \\
\hline Timber regeneration & Tim.r & stems ha ${ }^{-1}$ & $\begin{array}{c}182 \\
(10430)\end{array}$ & $\begin{array}{l}\text { Total density of regenerating juveniles, defined as having DBH between } \\
2.5 \text { and } 20 \mathrm{~cm} \text {, of } 28 \text { commercial timber genera }\end{array}$ \\
\hline Brazil nut trees & Berth & stems ha ${ }^{-1}$ & $\begin{array}{l}2.4 \\
(020)\end{array}$ & $\begin{array}{l}\text { Density of adult (DBH }>50 \mathrm{~cm} \text { ) Brazil nut (Bertholletia excelsa) trees } \\
\text { (Kainer et al. 2007) }\end{array}$ \\
\hline $\begin{array}{l}\text { Brazil nut } \\
\text { regeneration }\end{array}$ & Berth.r & stems ha ${ }^{-1}$ & $\begin{array}{c}5.2 \\
(080)\end{array}$ & $\begin{array}{l}\text { Density of regenerating juvenile (DBH between } 2.5 \text { and } 50 \mathrm{~cm} \text { ) Brazil } \\
\text { nut trees }\end{array}$ \\
\hline Rubber trees & Hevea & stems ha ${ }^{-1}$ & $\begin{array}{l}2.1 \\
(050)\end{array}$ & Density of adult $(\mathrm{DBH}>30 \mathrm{~cm})$ rubber (Hevea brasiliensis) trees \\
\hline Rubber regeneration & Hevea.r & stems ha ${ }^{-1}$ & $\begin{array}{l}7.5 \\
(040)\end{array}$ & $\begin{array}{l}\text { Density of regenerating juvenile (DBH between } 2.5 \text { and } 30 \mathrm{~cm} \text { ) rubber } \\
\text { trees }\end{array}$ \\
\hline Copaiba trees & Copaiba & stems ha ${ }^{-1}$ & $\begin{array}{ll}0.1 \\
(04)\end{array}$ & $\begin{array}{l}\text { Density of adult (DBH }>25 \mathrm{~cm} \text { ) copaiba (Copaiba spp.) trees (Newton } \\
\text { et al. 2012) }\end{array}$ \\
\hline $\begin{array}{l}\text { Copaiba } \\
\text { regeneration }\end{array}$ & Copaiba.r & stems ha ${ }^{-1}$ & 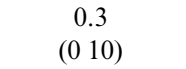 & $\begin{array}{l}\text { Density of regenerating juvenile (DBH between } 2.5 \text { and } 25 \mathrm{~cm} \text { ) copaiba } \\
\text { trees }\end{array}$ \\
\hline Açai trees & Acai & stems ha $^{-1}$ & $\begin{array}{l}14.5 \\
(0100)\end{array}$ & $\begin{array}{l}\text { Density of adult }(\mathrm{DBH}>10 \mathrm{~cm}) \text { açai (Euterpe precatoria) trees (Bernal } \\
\text { et al. 2011) }\end{array}$ \\
\hline Açai regeneration & Acai.r & stems ha ${ }^{-1}$ & $\begin{array}{l}21.5 \\
(0110)\end{array}$ & $\begin{array}{l}\text { Density of regenerating juvenile (DBH between } 2.5 \text { and } 10 \mathrm{~cm} \text { ) açai } \\
\text { trees }\end{array}$ \\
\hline
\end{tabular}

Fig. 1. A map illustrating the study area in southwestern Amazonia, including major highways (in red), the 69 sample plots (green crosses), and major urban centers (stars).

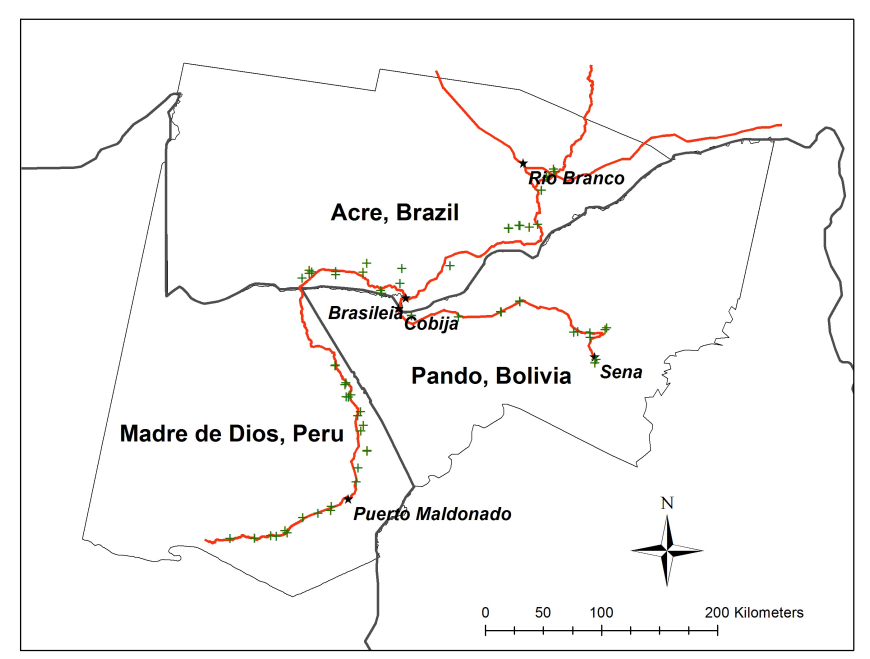

randomly chosen baseline. Each woody plant rooted within the transect area and with a diameter at breast height (DBH at 1.3 $\mathrm{m}$ ) of $\geq 2.5 \mathrm{~cm}$ was included and measured for both DBH and height. Where a plant had multiple stems, we recorded it as one individual, but took separate diameter and height measures for each stem to be used for calculations of aboveground biomass. We modified the original Gentry plot protocol to provide more accurate measures of forest biomass and timber and nontimber resources (Baraloto et al. 2013). Each 2 x $50 \mathrm{~m}$ subplot was extended to a $10 \times 50 \mathrm{~m}$ subplot in which all woody stems with diameter at breast height of $\geq 20 \mathrm{~cm}$ were sampled (Baraloto et al. 2011).

We collected voucher specimens for each species and whenever there was any uncertainty as to identity. Sampling was conducted from 2007 - 2010 as part of training courses for university students at the three local collaborating universities, and a full duplicate set of collections from each country is deposited in each of their three local herbaria (the National Amazonian University of Madre de Dios [UNAMAD] in Puerto Maldonado, Peru; the Center for Research on Amazon Protection of the Amazonian University of Pando [CIPA-UAP] in Cobija, Bolivia; and the Zoobotanical Park of the Federal University of Acre [PZ-UFAC] Rio Branco, Brazil). Samples have been cross-referenced among countries by the lead author, but because reference collections at these herbaria are under construction, we could identify many of our sterile specimens only to the genus level with confidence (Pitman et al. 2008). Overall, $93.5 \%$ of stems were assigned genus level identifications with confidence, and $99.5 \%$ were assigned to family level.

\section{Forest value components}

We estimated 15 variables describing forest value (forest value components; Table 1) in this region. First, we calculated indices describing woody plant diversity in each plot. We used the Simpson 
index to describe genus-level diversity, and the complementary Rao quadratic entropy to describe functional diversity (Pavoine and Bonsall 2011). The Rao index is analogous to the Simpson index but integrates pairwise differences among species in their functional traits. We applied a functional trait database describing leaf and wood tissue characteristics of more than 1200 species across the Amazon region (Baraloto et al. 2010, Fortunel et al. 2012). Trait values were applied to each individual in the sample by taxonomic correspondence. For species or genera in the plot data that were not present in the functional trait database, we substituted the mean values for all individuals pertaining to the next higher taxonomic level because these traits show weak but significant phylogenetic signal (Baraloto et al. 2012b). Of the 397 genera present in the dataset, 177 were assigned genus-level traits and 166 were assigned mean family level trait values.

Second, we estimated aboveground live biomass using allometric equations for different size classes as described in Baraloto et al. (2011). In particular, we estimated the aboveground biomass of smaller trees with DBH between 2.5 and $10 \mathrm{~cm}$, including palms, from a single equation modified from the model reported by Chave et al. (2004). Also, we estimated the aboveground biomass (AGB) in trees with $\mathrm{DBH}>10 \mathrm{~cm}$, including palms, using allometric formulas that integrate the species trait data on wood specific gravity (Chave et al. 2005). We also calculated AGB using allometries developed for the southern Amazon region by Nogueira et al. (2008). The two approaches gave very similar results across our plots $(r=0.98)$. To facilitate comparisons with other sites in the literature, we chose to report the allometries of Chave et al. (2004, 2005).

We also estimated three other indices that relate forest value to local livelihoods, including timber volume of commercial species harvested in the region and the abundance of principal NTFPs. We compiled a list of 28 commercially important genera/species complexes in the region (Table 2) based on interviews with community members (Perz et al. 2013). We calculated standing timber volume for stems of all commercial species with $\mathrm{DBH}>$ $45 \mathrm{~cm}$ in each plot using the Nogueira et al. (2008) allometry for the southern Amazon region. We also calculated future crop tree density of timber species (FCT; Rockwell et al. 2007) as the density of all trees of the same species group with DBH between 20 and $45 \mathrm{~cm}$, and the regeneration density as all stems with DBH between 2.5 and $20 \mathrm{~cm}$.

We identified four commercially important species as nontimber forest products in the region (Table 3) based on interviews with community members (Perz et al. 2013), including Brazil nut (Bertholletia excelsa, Lecythidaceae; Kainer et al. 2007), rubber (Hevea brasiliensis; Euphorbiaceae, Duchelle et al. 2012), açai (Euterpe precatoria, Arecaceae; Bernal et al. 2011) and copaiba oil (Copaifera spp., Fabaceae; Newton et al. 2012). For each of these taxa, we estimated the density of productive adults, defined here for each species as the size at which the product (fruit, latex, oil) is harvested; and we estimated the density of regeneration as all stems between $2.5 \mathrm{~cm} \mathrm{DBH}$ and the productive adult minimum size (Table 1). Although we do not consider this to be an exhaustive list of NTFP species, these four species are particularly important. Several other species that are common in the region have been noted for potential commercialization (e.g., seeds of Carapa spp., Meliaceae, Klimas et al. 2012), viable markets for these products do not currently exist, so we opted not to consider
Table 2. Major commercial timber genera, common names, and examples of 2012 market values from Acre, Brazil. Genera were included when cited as among those that could be sold consistently outside local communities. Shown are values paid to smallholders per cubic meter of standing roundwood before harvest, with sawnwood values in capital city sawmills indicated in parentheses. Despite its high quality timber and traditional use, market restrictions limit trade for Bertholletia excelsa.

\begin{tabular}{|c|c|c|c|}
\hline Genus & Family & Common Names & $\begin{array}{l}\text { Value } \\
(\$ \mathrm{R})^{\dagger}\end{array}$ \\
\hline Amburana & Fabaceae & Cerejeira & $40(850)$ \\
\hline Andira & Fabaceae & Angelim & $40(750)$ \\
\hline Apuleia & Fabaceae & Cumaru cetim & $40(1250)$ \\
\hline Aspidosperma & Apocynaceae & $\begin{array}{l}\text { Amarelão, } \\
\text { carapanauba }\end{array}$ & $40(850)$ \\
\hline Astronium & Anacardiaceae & Muiracatiara & $40(750)$ \\
\hline Brosimum & Moraceae & Inharé, mururé & $40(700)$ \\
\hline Carapa & Meliaceae & Andiroba & $\begin{array}{c}40 \\
\text { (no market) }\end{array}$ \\
\hline Cedrela & Meliaceae & Cedro & $40(1300)$ \\
\hline Ceiba & Malvaceae & Samauma & $40(750)$ \\
\hline Clarisia & Moraceae & Guariuba & $40(750)$ \\
\hline Copaifera & Fabaceae & Copaiba & $40(850)$ \\
\hline Couratari & Lecythidaceae & Tauari & $40(750)$ \\
\hline Diplotropis & Fabaceae & Sucupira & $40(850)$ \\
\hline Dipteryx & Fabaceae & Cumaru ferro & $40(1350)$ \\
\hline Enterolobium & Fabaceae & Fava orelinha & $40(850)$ \\
\hline Hymenaea & Fabaceae & Jatoba, jutai & $40(950)$ \\
\hline Hymenolobium & Fabaceae & Angelim & $40(750)$ \\
\hline Jacaranda & Bignoniaceae & Marupa & $40(750)$ \\
\hline Manilkara & Sapotaceae & Maçaranduba & $40(850)$ \\
\hline Mezilaurus & Lauraceae & Itauba & $40(850)$ \\
\hline Myroxylon & Fabaceae & Balsamo & $40(850)$ \\
\hline Parkia & Fabaceae & Angico & $40(750)$ \\
\hline Peltogyne & Fabaceae & Roxinho & $40(850)$ \\
\hline Swietenia & Meliaceae & Mogno & $\begin{array}{l}\text { Rare, price } \\
\text { negotiated }\end{array}$ \\
\hline Tabebuia & Bignoniaceae & Ipe, pau d'arco & $40(850)$ \\
\hline Terminalia & Combretaceae & Imbirindiba & $40(750)$ \\
\hline Tetragastris & Burseraceae & Breu vermelho & $40(850)$ \\
\hline Vochysia & Vochysiaceae & Catuaba & $40(750)$ \\
\hline \multicolumn{4}{|c|}{${ }^{\dagger} 1$ Brazilian real $=$ US $\$ 0.49$} \\
\hline
\end{tabular}

them here. Thus, we consider our NTFP index to be a reasonable indicator of value as perceived by local community members.

We analyzed relationships among the forest value components using pairwise correlations and principal components analysis, with $\log$ transformations where necessary. All analyses were performed in the $\mathrm{R}$ statistical platform ( $\mathrm{R}$ Development Core Team 2012).

\section{RESULTS}

Across the 69 plots, we sampled 15,314 stems representing 87 families, 397 genera, and at least 1009 species. The most abundant genera we sampled for understory trees (DBH between 2.5 and $10 \mathrm{~cm}$ ) were Rinorea (Violaceae, $4.9 \%$ of stems), Siparuna (Siparunaceae, 4.2\%), Pausandra (Euphorbiaceae, 3.5\% of stems), Tetragastris (Burseraceae, 3.4\% of stems), and Inga (Fabaceae, 3.3\% of stems); for mid-size trees (DBH between 10 and $30 \mathrm{~cm})$, the most abundant genera were Tetragastris $(5.4 \%$ of 
Table 3. Nontimber forest product species, common names, and examples of 2012 market values from Acre, Brazil.

\begin{tabular}{|c|c|c|c|c|}
\hline$\overline{\text { Genus }}$ & Family & Common Names & Part used & $\begin{array}{l}\text { Value } \\
(\$ R)^{\dagger}\end{array}$ \\
\hline Bertholletia & Lecythidaceae & Castanha & Seed (and timber) & $15-20 /$ lata $^{\ddagger}$ \\
\hline Hevea & Euphorbiaceae & Seringa & Latex & $7.8 / \mathrm{kg}$ \\
\hline Copaifera & Fabaceae & Copaiba & Sap (and timber) & 40/liter \\
\hline Euterpe & Arecaceae & asai & Fruit (and stem heart) & $10-18 /$ lata \\
\hline
\end{tabular}

stems), Pseudolmedia (Moraceae, $4.7 \%$ of stems), Euterpe (Arecaceae, 3.9\%), Iriartea (Arecaceae, $2.9 \%$ of stems), and Inga (2.6\% of stems); and for large trees (with DBH greater than 30 $\mathrm{cm})$, the most abundant genera were Tetragastris (10.3\% of stems), Pseudolmedia (4.1\% of stems), Brosimum (Moraceae, 3.8\%), Cecropia (Cecropiaceae, 3.5\% of stems), Bertholletia $(2.9 \%$ of stems), and Pouteria (Sapotaceae, 2.9\% of stems).

Principal components analysis revealed two primary axes which together explained more than a third of the variation among the 15 forest value components (Fig. 2). The first axis described a trade-off between plots with high tree diversity vs. high aboveground biomass (Fig. 2), with strong positive loadings for both taxonomic and functional diversity as well as strong negative loadings for variables describing forest structure, including aboveground biomass and timber stocks (Table 4). The second axis synthesized the abundance of many commercial species, since it was driven by the abundance of adults and regeneration of timber and many NTFP species (Fig. 2) and also included strong loadings for aboveground biomass (Table 4).

Fig. 2. Biplot of principal components analysis illustrating correlations among forest value components, which are indicated along arrows using abbreviations from Table 1. Ordinations of the 69 forest sample plots are illustrated as grey circles. See Table 4 for complete results of correlation analyses and principal components analysis (PCA) loadings of forest value components.

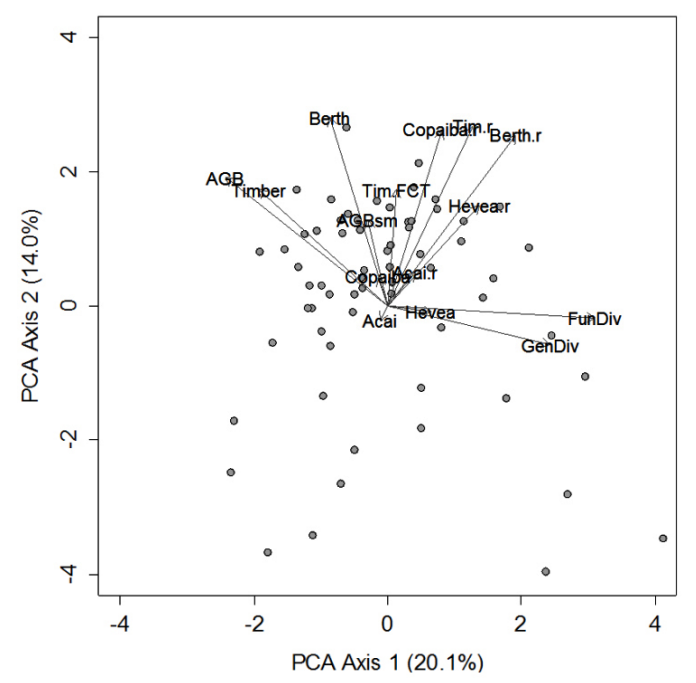

Figure 3 illustrates the pairwise relationships underpinning the multivariate findings. Even the stronger correlations in our dataset are characterized by some variation. For example, sites with the lowest tree diversity maintained median values of functional diversity in the region (Fig. 3a). This suggests that even though these metrics are highly positively correlated, they may still be providing complementary information for management. Biplots also show that the sites with higher tree diversity tend to have lower timber volume and aboveground biomass, but that low tree diversity occurs in situations across a range of values of forest biomass and timber volume (Fig. 3 b-c).

Fig. 3. Biplots of forest value components defining major axes of variation across the 69 sampled plots in southwestern Amazonia. Functional Diversity (Rao's Q) vs (a) Taxonomic Diversity (Simpson), (b) aboveground biomass, and (c) harvestable volume of commercial timber species.
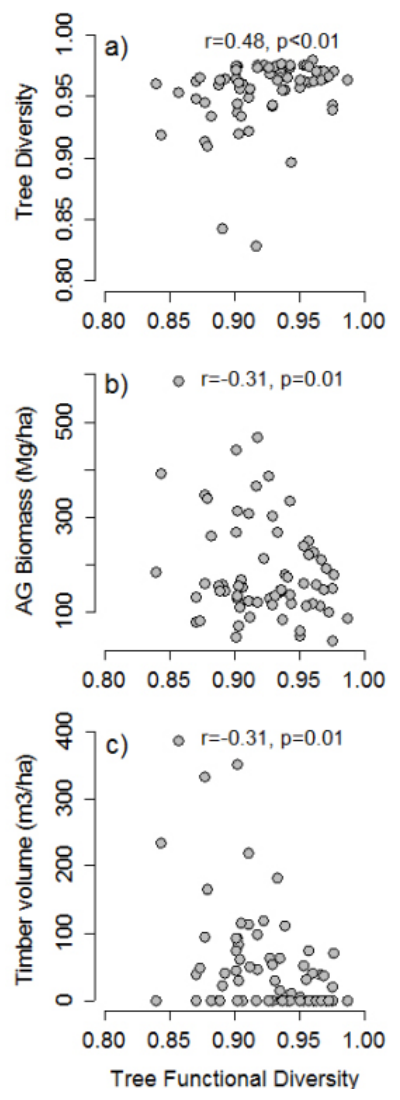
Table 4. Correlations among forest value components (see Table 1 for details) across the 69 plots, and loadings on the first two axes of a principal components analysis (PCA). Significant correlations and loadings are indicated in bold.

\begin{tabular}{|c|c|c|c|c|c|c|c|c|c|c|c|c|c|c|c|c|}
\hline & PCA 1 & PCA 2 & TreeDiv & FunDiv & AGB10 & AGBsm & Timber & TimFCT & Tim.r & Berth & Berth.r & Hevea & $\begin{array}{c}\text { Hevea. } \\
\mathrm{r}\end{array}$ & Copaiba & $\begin{array}{c}\text { Copaiba. } \\
\text { r }\end{array}$ & Acai \\
\hline TreeDiv & -0.606 & -0.145 & & & & & & & & & & & & & & \\
\hline FunDiv & -0.776 & -0.045 & 0.48 & & & & & & & & & & & & & \\
\hline AGB10 & 0.606 & 0.479 & -0.19 & -0.31 & & & & & & & & & & & & \\
\hline AGBsm & 0.074 & 0.322 & -0.35 & -0.04 & -0.03 & 1 & & & & & & & & & & \\
\hline Timber & 0.483 & 0.435 & -0.1 & -0.31 & 0.52 & -0.01 & & & & & & & & & & \\
\hline $\begin{array}{l}\text { TimF- } \\
\text { CT }\end{array}$ & -0.032 & 0.435 & 0.02 & 0.09 & 0.28 & 0.16 & 0.13 & & & & & & & & & \\
\hline Tim.r & -0.318 & 0.670 & -0.02 & 0.13 & -0.04 & 0.4 & 0.07 & 0.21 & & & & & & & & \\
\hline Berth & 0.218 & 0.703 & -0.19 & -0.15 & 0.5 & 0.13 & 0.19 & 0.12 & 0.42 & & & & & & & \\
\hline Berth.r & -0.479 & 0.637 & 0.08 & 0.21 & -0.04 & 0.02 & 0 & 0.12 & 0.55 & 0.31 & & & & & & \\
\hline Hevea & -0.164 & -0.020 & 0.09 & 0.08 & 0.03 & -0.05 & 0.01 & 0.04 & -0.04 & -0.08 & -0.06 & & & & & \\
\hline $\begin{array}{l}\text { Hevea. } \\
\mathrm{r}\end{array}$ & -0.342 & 0.376 & 0.07 & 0.16 & 0.02 & 0.08 & 0.07 & 0.21 & 0.23 & 0.15 & 0.25 & 0.43 & & & & \\
\hline Copaiba & 0.027 & -0.053 & -0.12 & -0.04 & -0.15 & 0.15 & 0.06 & -0.1 & 0.21 & -0.08 & -0.04 & 0.01 & -0.05 & & & \\
\hline $\begin{array}{l}\text { Copai- } \\
\text { ba.r }\end{array}$ & -0.101 & 0.126 & 0.02 & -0.06 & -0.06 & 0.09 & -0.01 & -0.02 & 0.17 & -0.01 & 0 & -0.05 & 0.12 & -0.04 & & \\
\hline Acai & 0.036 & 0.105 & 0.12 & 0.1 & 0.11 & 0.1 & 0.05 & 0.25 & -0.14 & 0.04 & -0.16 & 0.09 & -0.1 & -0.15 & -0.11 & \\
\hline Acai.r & -0.202 & 0.653 & 0.1 & 0.11 & 0.17 & 0.03 & 0.29 & 0.13 & 0.26 & 0.28 & 0.59 & -0.12 & 0.11 & -0.13 & 0.13 & 0.31 \\
\hline
\end{tabular}

\section{DISCUSSION}

Our study represents one of the first descriptions of relationships among different components of tropical forest value, especially for smallholders whose livelihoods may depend both on harvesting diverse forest products and obtaining payments or technical assistance from government programs related to carbon conservation (see Duchelle et al. 2014). We found strong evidence for geographic trade-offs between woody plant diversity and variables describing forest structure, including timber stocks and aboveground biomass (Fig. 2). Indeed, very few individual sites showed high values of tree diversity, aboveground biomass, and timber stocks. These results contradict global analyses suggesting that initiatives such as REDD+ that target conservation projects in areas rich in carbon stocks will also protect areas of high biodiversity value (Venter et al. 2009, Strassburg et al. 2010). Instead, our results support other studies showing a discord between geographic priorities for carbon-based conservation and biodiversity conservation (Paoli et al. 2010, Siikamäki and Newbold 2012, Thomas et al. 2013). Our results are also consistent with other Amazon basin wide analyses which tend to show higher levels of plant diversity in areas characterized by lower aboveground biomass, perhaps due to increased rates of forest dynamics on more fertile soils (Quesada et al. 2012).

Our results should nevertheless be interpreted with some caution, for at least two reasons. First, we measured only one taxonomic group, woody plants. Although woody plants show relatively high performance as an indicator group for the diversity of other taxa in comprehensive comparisons (Gardner et al. 2008), they may be less sensitive to landscape disturbances than invertebrate groups (Schulze et al. 2004). In addition, our estimates of woody plant diversity were constrained by the taxonomic precision with which we could identify collections. Nevertheless, the genus-level measures of diversity we adopted mimic those used by Gardner et al. (2008), and represented substantial diversity within this region, with nearly 400 genera collected. A higher level of taxonomic precision may also allow a more precise disentangling of the strong correlation we observed between taxonomic and functional diversity in this study (Table 4). Functional diversity represents an appropriate measure of diversity for both international and local stakeholder perceptions of forest value because it has been directly linked to important ecosystem processes, including carbon and hydrological cycles (Lavorel 2013).

Beyond the trade-off between forest structure and tree diversity, we found a consistent positive correlation among the relative abundances of many commercial species, including both timber and NTFPs, and aboveground biomass (Table 4). This finding suggests that multiple use forest management, in which incomes from NTFP extraction may be supplemented by low intensity timber extraction, has some potential in this region. We sampled several sites where multiple forest products such as timber and Brazil nuts are relatively abundant (Fig. 2). However, multiple use approaches will still need to mitigate conflicts between harvesting of timber vs. NTFPs (Guariguata et al. 2008, Duchelle et al. 2012, Herrero-Jáuregui et al. 2013, Rockwell et al. 2014). Some species in particular may present conflicts of use because they are harvested for both timber and NTFPs (e.g., Dipteryx spp., Shanley et al. 2012; Copaifera spp., Newton et al. 2012; Carapa spp., Klimas et al. 2012). Mitigation of these conflicts of use will require species-specific forest inventories beyond the approach we have used here, to support legislation for sustainable management (Herrero-Jáuregui et al. 2013).

The observed positive correlation among abundances of many commercial species also underlines that whereas some forests had very high forest value, with up to an estimated US\$7700 per ha in standing timber stocks (see Table 2) and up to US\$880 per ha per year from collection of NTFPs (see Table 3), others had negligible value using the same criteria. This suggests that some smallholders may be limited in their options for multiple use forest management by the limited availability of resources in their 
landholding (Duchelle et al. 2012) and by undeveloped markets for a greater diversity of NTFPs, especially in Pando and Madre de Dios.

\section{Forest value components in the southwestern Amazon}

Each of the 15 components we describe showed relatively high variability (Table 1), but our results were broadly consistent with the few values that have been reported from this understudied region. Our estimate of aboveground biomass (mean $192 \mathrm{Mg} \mathrm{ha}^{-1}$ ) is largely concordant with other plot-based studies from the region (Phillips et al. 2006, Salimon et al. 2011) and supports the assertion that the smaller plots we used can provide accurate measures of local biomass (Baraloto et al. 2013).

In addition, our estimates of timber volume for the entire region (mean of $57 \mathrm{~m}^{3} \mathrm{ha}^{-1}$ ) are completely concordant with those recently reported for unlogged bamboo-dominated forests in Acre, Brazil (mean of $58 \mathrm{~m}^{3} \mathrm{ha}^{-1}$; Rockwell et al. 2014). Nevertheless, few other reliable estimates exist for timber availability throughout the region. One major limitation of forest inventories in the region remains the proper identification of timber tree species during forest management inventories and the development of a consistent list of commercially valuable species (Baraloto et al. 2007). Here we considered all species for which smallholders have been observed to receive payments for wood in recent years, even though some of these species are not commonly sold as sawnwood in local markets and others may be harvested for personal construction use rather than to be sold in local or regional markets (Table 2).

Our estimates for Brazil nut density are very similar to those reported by Peres et al. (2003) across the Amazon basin, including the lower densities reported in Peru (0.1 - 0.7 reported from Madre de Dios vs. 0.6 in our study) and higher densities reported for Pando ( 3.3 vs. 4.1 in our study). We also found relatively low densities of juveniles consistent with the recruitment limitation reported for the species in areas of intense fruit harvest (Peres et al. 2003). Despite the consistency between our results and the recent literature, we suggest that a more accurate description of forest value for many of the less frequent timber species or nontimber forest products would require complete inventories over larger surface areas.

Indeed, Newton et al. (2012) found mean density of adult Copaifera trees in terra firme forest of Amazonas around 1 stem per hectare $(0.83-1.13$ at local scale); they also report similar values for other studies they found in the literature. We found a much lower density of Copaifera adults in the region and limited regeneration (Table 1), suggesting that this species receive further attention for conflicts in use for timber extraction vs. oil production, including broader and more intensive forest inventories. We also found fewer stems of Euterpe precatoria (mean of 14.1 stems per hectare) than reported in a northern Bolivian forest (22.6 adult stems per hectare; Cabrera and Wallace 2007), but the high density of this species in both the terra firme forests we studied and the adjacent seasonally flooded forests, and its broad distribution, render it a very important and reliable species. In fact, we estimate that it could generate as much or more income as Brazil nut in many of the forests we studied (Table 3), such that it merits greater attention in multiple use management programs in the region (Duchelle et al. 2012).

\section{CONCLUSION}

Our regional study across this trinational frontier in southwestern Amazonia illustrates strong geographic trade-offs between woody plant diversity versus timber stocks and aboveground biomass. These results suggest that at this geographic scale, management strategies will need to prioritize either carbon stocks or biodiversity conservation. We also found substantial geographic variation in the distribution of commercial species, with some sites extremely rich in multiple forest products and others extremely poor. This patchiness of resource availability needs to be considered in tropical regions where smallholder forest management relies on sustainable harvests of multiple forest products.

\section{PERSPECTIVES}

Our description of selected components of forest value represents an initial foundation upon which more comprehensive analyses could be developed. As Sheil and Wunder (2002) note, valuation studies must integrate not only external perceptions of forest value but also local perceptions that result in decision making regarding forest conversion or resource exploitation. An integrative metric of forest value must then consider not only those components of forest value related to international markets and payments for ecosystem services and products of local economic value, such as timber and NTFPs, as we measured here, but also products that may not be sold but that contribute to local livelihoods, including construction materials, forest foods, medicines, and subsistence hunting resources (Godoy and Bawa 1993). We are currently working to develop methods for appropriate field inventories of multiple forest products across larger regions as in this trinational border area (Baraloto et al. 2013). Any valuation study must also consider that markets can be capricious, and static analyses may not be able to provide accurate predictions of future markets (Godoy et al. 2000).

As a basis for this future research, one of the important results of the project has been the capacity built by this international collaboration, which we believe is noteworthy for several reasons. First, in addition to general university training, with more than 50 students learning field inventory and herbarium curation methods, we have trained parataxonomists in communities across the region, many of whom have found employment with forest management initiatives. In addition, more than 4000 herbarium samples were deposited in herbaria throughout the region, which will help the necessary but underfunded work of building reference collections to improve efforts to improve regional floristic knowledge and gain precision in forest management inventories (Baraloto et al. 2007).

Responses to this article can be read online at: http://www.ecologyandsociety.org/issues/responses. $\mathrm{php} / 6911$

\section{Acknowledgments:}

This study was supported by US NSF grants HSD 0527511 and CNH 1114924, the French agriculture ministry (MAAP BGF grant), and an INRA Package grant to CB. This work has also 
benefited from an "Investissements d'Avenir " grant managed by Agence Nationale de la Recherche (CEBA, ref. ANR-10$L A B X-25-01)$. We thank the institutions supporting the training courses that were the foundation of fieldwork in the three countries, including Centro do Trabalhadores da Amazonia (CTA) in Rio Branco, Acre, and the Center for Research on Amazon Protection (CIPA) in Cobija, Pando; and the numerous students and community members in the three countries who provided assistance with fieldwork. We are also grateful to the taxonomic specialists who are investing in capacity building in the region and who assisted with the identification of botanical specimens from the project, including P. Acevedo Rodriguez, C. Berg, D. Daly, R. Foster, and C. Vriesendorpp. We also thank Amy Duchelle and Mary Menton for comments on previous versions of the manuscript.

\section{LITERATURE CITED}

Ahmed, S. E., and R. M. Ewers. 2012. Spatial pattern of standing timber value across the Brazilian Amazon. PLoS One 7:e36099. http://dx.doi.org/10.1371/journal.pone.0036099

Angelsen, A., and M. Brockhaus. 2009. Realising REDD+: national strategy and policy options. Center for International Forestry Research, Bogor, Indonesia.

Asner, G. P., W. Llactayo, R. Tupayachi, and E. R. Luna. 2013. Elevated rates of gold mining in the Amazon revealed through high-resolution monitoring. Proceedings of the National Academy of Sciences 110:18454-18459. http://dx.doi.org/10.1073/pnas.1318271110

Asner, G. P., S. R. Loarie, and U. Heyder. 2010. Combined effects of climate and land-use change on the future of humid tropical forests. Conservation Letters 3:395-403. http://dx.doi.org/10.1111/ j.1755-263X.2010.00133.X

Balmford, A., A. Bruner, P. Cooper, R. Costanza, S. Farber, R. E. Green, M. Jenkins, P. Jefferiss, V. Jessamy, J. Madden, K. Munro, N. Myers, S. Naeem, J. Paavola, M. Rayment, S. Rosendo, J. Roughgarden, K. Trumper, and R. K. Turner. 2002. Economic reasons for conserving wild nature. Science 297:950-953. http:// dx.doi.org/10.1126/science. 1073947

Baraloto, C., O. J. Hardy, C. E. T. Paine, K. G. Dexter, C. Cruaud, L. T. Dunning, M.-A. Gonzalez, J.-F. Molino, D. Sabatier, V. Savolainen, and J. Chave. 2012b. Using functional traits and molecular phylogenetic trees to examine the assembly of tropical tree communities. Journal of Ecology 100:690-701. http://dx.doi. org/10.1111/j.1365-2745.2012.01966.X

Baraloto, C., B. Hérault, C. E. T. Paine, H. Massot, L. Blanc, D. Bonal, J.-F. Molino, E. A. Nicolini, and D. Sabatier. $2012 a$. Contrasting taxonomic and functional responses of a tropical tree community to selective logging. Journal of Applied Ecology 49:861-870. http://dx.doi.org/10.1111/j.1365-2664.2012.02164.x

Baraloto, C., Q. Molto, S. Rabaud, B. Hérault, R. Valencia, L. Blanc, P. V. A. Fine, and J. Thompson. 2013. Rapid simultaneous estimation of aboveground biomass and tree diversity across neotropical forests: a comparison of field inventory methods. Biotropica 45:288-298. http://dx.doi.org/10.1111/btp.12006

Baraloto, C., C. E. T. Paine, L. Poorter, J. Beauchene, D. Bonal, A.-M. Domenach, B. Hérault, S. Patiño, J.-C. Roggy, and J. Chave. 2010. Decoupled leaf and stem economics in rainforest trees. Ecology Letters 13:1338-1347. http://dx.doi.org/10.1111/ j.1461-0248.2010.01517.x
Baraloto, C., S. Rabaud, Q. Molto, L. Blanc, C. Fortunel, B. Hérault, N. Dávila, I. Mesones, M. Rios, E. Valderrama, and P. V. A. Fine. 2011. Disentangling stand and environmental correlates of aboveground biomass in Amazonian forests. Global Change Biology 17:2677-2688. http://dx.doi.org/10.1111/ j.1365-2486.2011.02432.x

Baraloto, C., C. Rockwell, F. Walthier, and E. Ferreira. 2007. Limitations and applications of paratoxonomy for community forest management in southwestern amazonia. Ethnobotany Research and Applications 5:75-84.

Bernal, R., C. Torres, N. García, C. Isaza, J. Navarro, M. I. Vallejo, G. Galeano, and H. Balslev. 2011. Palm management in South America. Botanical Review 77:607-646. http://dx.doi.org/10.1007/ s12229-011-9088-6

Cabrera, W. H., and R. Wallace. 2007. Densidad y distribución espacial de palmeras arborescentes en un bosque preandinoamazónico de Bolivia. Ecología en Bolivia 42:121-135.

Chave, J., C. Andalo, S. Brown, M. Cairns, J. Chambers, D. Eamus, H. Fölster, F. Fromard, N. Higuchi, T. Kira, T. Kira, J.-P. Lescure, B. W. Nelson, H. Ogawa, H. Puig, B. Riéra, and T. Yamakura. 2005. Tree allometry and improved estimation of carbon stocks and balance in tropical forests. Oecologia 145:87-99. http://dx.doi. org/10.1007/s00442-005-0100-X

Chave, J., R. Condit, S. Aguilar, A. Hernandez, S. Lao, and R. Perez. 2004. Error propagation and scaling for tropical forest biomass estimates. Philosophical Transactions of the Royal Society of London. Series B: Biological Sciences 359:409-420. http://dx. doi.org/10.1098/rstb.2003.1425

Chisholm, R. A. 2010. Trade-offs between ecosystem services: water and carbon in a biodiversity hotspot. Ecological Economics 69:1973-1987. http://dx.doi.org/10.1016/j.ecolecon.2010.05.013

de Bello, F., S. Lavorel, S. Díaz, R. Harrington, J. H. Cornelissen, R. D. Bardgett, M. P. Berg, P. Cipriotti, C. K. Feld, D. Hering, et al. 2010. Towards an assessment of multiple ecosystem processes and services via functional traits. Biodiversity and Conservation 19:2873-2893. http://dx.doi.org/10.1007/s10531-010-9850-9

Duchelle, A. E., M. Cromberg, M. F. Gebara, R. Guerra, T. Melo, A. Larson, P. Cronkleton, J. Börner, E. Sills, S. Wunder, S. Bauch, P. May, G. Selaya, and W. D. Sunderlin. 2014. Linking forest tenure reform, environmental compliance, and incentives: lessons from REDD+ initiatives in the Brazilian Amazon. World Development 55:53-67. http://dx.doi.org/10.1016/j.worlddev.2013.01.014

Duchelle, A. E., M. Guariguata, G. Less, A. Chavez, M. A. Albornoz, A. Chavez, and T. Melo. 2012. Evaluating the opportunities and limitations to multiple use of Brazil nuts and timber in Western Amazonia. Forest Ecology and Management 268:39-48. http://dx.doi.org/10.1016/j.foreco.2011.05.023

Fortunel, C., P. V. A. Fine, and C. Baraloto. 2012. Leaf, stem and root tissue strategies across 758 Neotropical tree species. Functional Ecology 26:1153-1161. http://dx.doi.org/10.1111/ j.1365-2435.2012.02020.x

Gardner, T. A., J. Barlow, I. S. Araujo, T. C. Ávila-Pires, A. B. Bonaldo, J. E. Costa, M. C. Esposito, L. V. Ferreira, J. Hawes, M. I. M. Hernandez, M. S. Hoogmoed, R. N. Leite, N. F. Lo-ManHung, J. R. Malcolm, M. B. Martins, L. A. M. Mestre, R. Miranda-Santos, W. L. Overal, L. Parry, S. L. Peters, M. A. 
Ribeiro-Junior, M. N. F. Da Silva, C. Da Silva Motta, and C. A. Peres. 2008. The cost-effectiveness of biodiversity surveys in tropical forests. Ecology Letters 11:139-150. http://dx.doi. org/10.1111/j.1461-0248.2007.01133.x

Gardner, T. A., N. D. Burgess, N. Aguilar-Amuchastegui, J. Barlow, E. Berenguer, T. Clements, F. Danielsen, J. Ferreira, W. Foden, V. Kapos, et al. 2012. A framework for integrating biodiversity concerns into national REDD+ programmes. Biological Conservation 154:61-71. http://dx.doi.org/10.1016/j. biocon.2011.11.018

Godoy, R. A., and K. S. Bawa. 1993. The economic value and sustainable harvest of plants and animals from the tropical forest: assumptions, hypotheses, and methods. Economic Botany 47:215-219. http://dx.doi.org/10.1007/BF02862287

Godoy, R., D. Wilkie, H. Overman, A. Cubas, G. Cubas, J. Demmer, K. McSweeney, and N. Brokaw. 2000. Valuation of consumption and sale of forest goods from a Central American rain forest. Nature 406:62-63. http://dx.doi.org/10.1038/35017647

Gomes, C. V. A., J. M. Vadjunec, and S. G. Perz. 2012. Rubber tapper identities: political-economic dynamics, livelihood shifts, and environmental implications in a changing Amazon. Geoforum 43:260-271. http://dx.doi.org/10.1016/j.geoforum.2011.09.005

Guariguata, M. R., P. Cronkleton, P. Shanley, and P. L. Taylor. 2008. The compatibility of timber and non-timber forest product extraction and management. Forest Ecology and Management 256:1477-1481. http://dx.doi.org/10.1016/j.foreco.2008.03.038

Guariguata, M. R., C. García-Fernández, D. Sheil, R. Nasi, C. Herrero-Jáuregui, P. Cronkleton, and V. Ingram. 2010. Compatibility of timber and non-timber forest product management in natural tropical forests: perspectives, challenges, and opportunities. Forest Ecology and Management 259:237-245. $\underline{\text { http://dx.doi.org/10.1016/j.foreco.2009.11.013 }}$

Hajek, F., M. J. Ventresca, J. Scriven, A. Castro. 2011. Regimebuilding for REDD+: evidence from a cluster of local initiatives in south-eastern Peru. Environmental Science and Policy 14:201-215. http://dx.doi.org/10.1016/j.envsci.2010.12.007

Herrero-Jáuregui, C., M. R. Guariguata, D. Cárdenas, E. Vilanova, M. Robles, J. C. Licona, and W. Nalvarte. 2013. Assessing the extent of "conflict of use" in multipurpose tropical forest trees: a regional view. Journal of Environmental Management 130:40-47. http://dx.doi.org/10.1016/j.jenvman.2013.08.044

Hirsch, P. D., W. M. Adams, J. P. Brosius, A. Zia, N. Bariola, and J. L. Dammert. 2011. Acknowledging conservation trade-offs and embracing complexity. Conservation Biology 25:259-264. http:// dx.doi.org/10.1111/j.1523-1739.2010.01608.X

Hosonuma, N., M. Herold, V. De Sy, R. S. De Fries, M. Brockhaus, L. Verchot, A. Angelsen, and E. Romijn. 2012. An assessment of deforestation and forest degradation drivers in developing countries. Environmental Research Letters 7:044009. http://dx.doi.org/10.1088/1748-9326/7/4/044009

Hughes, R. F., J. B. Kauffman, and V. J. Jaramillo. 1999. Biomass, carbon, and nutrient dynamics of secondary forests in a humid tropical region of Mexico. Ecology 80:1892-1907.

Kainer, K. A., L. H. Wadt, and C. L. Staudhammer. 2007. Explaining variation in Brazil nut fruit production. Forest Ecology and Management 250:244-255. http://dx.doi.org/10.1016/j. foreco.2007.05.024

Klimas, C. A., K. A. Kainer, and L. H. de Oliveira Wadt. 2012. The economic value of sustainable seed and timber harvests of multi-use species: an example using Carapa guianensis. Forest Ecology and Management 268:81-91. http://dx.doi.org/10.1016/j. foreco.2011.03.006

Lavorel, S. 2013. Plant functional effects on ecosystem services. Journal of Ecology 101:4-8. http://dx.doi.org/10.1111/1365-2745.12031

Le Saout, S., M. Hoffmann, Y. Shi, A. Hughes, C. Bernard, T. M. Brooks, B. Bertzky, S. H. M. Butchart, S. N. Stuart, T. Badman, and A. S. L. Rodrigues. 2013. Protected areas and effective biodiversity conservation. Science 342:803-805. http://dx.doi. org/10.1126/science. 1239268

Mouillot, D., S. Villéger, M. Scherer-Lorenzen, and N. W. Mason. 2011. Functional structure of biological communities predicts ecosystem multifunctionality. PLoS One 6:e17476. http://dx.doi. org/10.1371/journal.pone.0017476

Newton, P., A. Watkinson, and C. Peres. 2012. Spatial, temporal, and economic constraints to the commercial extraction of a nontimber forest product: copaíba (Copaifera spp.) oleoresin in Amazonian reserves. Economic Botany 66:165-177. http://dx.doi. org/10.1007/s12231-012-9198-Z

Ninan, K., and M. Inoue. 2013. Valuing forest ecosystem services: what we know and what we don't. Ecological Economics 93:137-149. http://dx.doi.org/10.1016/i.ecolecon.2013.05.005

Nogueira, E. M., P. M. Fearnside, B. W. Nelson, R. I. Barbosa, and E. W. H. Keizer. 2008. Estimates of forest biomass in the Brazilian Amazon: new allometric equations and adjustments to biomass from wood-volume inventories. Forest Ecology and Management 256:1853-1867. http://dx.doi.org/10.1016/j. foreco.2008.07.022

Paoli, G. D., P. L. Wells, E. Meijaard, M. J. Struebig, A. J. Marshall, K. Obidzinski, A. Tan, A. Rafiastanto, B. Yaap, J. W. F. Slik, et al. 2010. Biodiversity conservation in the REDD. Carbon Balance and Management 5:7. http://dx.doi. org/10.1186/1750-0680-5-7

Parviainen, J., and G. Frank. 2003. Protected forests in Europe approaches-harmonising the definitions for international comparison and forest policy making. Journal of Environmental Management 67:27-36. http://dx.doi.org/10.1016/S0301-4797(02) 00185-8

Pavoine, S., and M. Bonsall. 2011. Measuring biodiversity to explain community assembly: a unified approach. Biological Reviews 86:792-812. http://dx.doi.org/10.1111/j.1469-185X.2010.00171. $\underline{\mathrm{X}}$

Peres, C. A., C. Baider, P. A. Zuidema, L. H. Wadt, K. A. Kainer, D. A. P. Gomes-Silva, R. P. Salomão, L. L. Simões, E. R. Franciosi, F. C. Valverde, et al.. 2003. Demographic threats to the sustainability of Brazil nut exploitation. Science 302:2112-2114. http://dx.doi.org/10.1126/science.1091698

Perz, S. G., Y. Qiu, Y. Xia, J. Southworth, J. Sun, M. Marsik, K. Rocha, V. Passos, D. Rojas, G. Alarcón, G. Barnes, and C. Baraloto. 2013. Trans-boundary infrastructure and land cover change: highway paving and community-level deforestation in a 
tri-national frontier in the Amazon. Land Use Policy 34:27-41. http://dx.doi.org/10.1016/j.landusepol.2013.01.009

Peters, C. M., A. H. Gentry, and R. O. Mendelsohn. 1989. Valuation of an Amazonian rainforest. Nature 339:655-656. http://dx.doi.org/10.1038/339655a0

Phelps, J., D. A. Friess, and E. L. Webb. 2012a. Win-win REDD+ approaches belie carbon-biodiversity trade-offs. Biological Conservation 154:53-60. http://dx.doi.org/10.1016/j.biocon.2011.12.031

Phelps, J., E. L. Webb, and W. M. Adams. 2012b. Biodiversity cobenefits of policies to reduce forest-carbon emissions. Nature Climate Change 2:497-503.

Phillips, O. L., R. V. Martínez, P. N. Vargas, A. L. Monteagudo, M.-E. C. Zans, W. G. Sánchez, A. P. Cruz, M. Timaná, M. YliHalla, and S. Rose. 2003. Efficient plot-based floristic assessment of tropical forests. Journal of Tropical Ecology 19:629-645. http:// dx.doi.org/10.1017/S0266467403006035

Phillips, O. L., S. Rose, A. L. Monteagudo, and P. N. Vargas. 2006. Resilience of southwestern Amazon forests to anthropogenic edge effects. Conservation Biology 20:1698-1710. http://dx.doi. org/10.1111/j.1523-1739.2006.00523.X

Pitman, N. C., H. Mogollón, N. Dávila, M. Ríos, R. GarcíaVillacorta, J. Guevara, T. R. Baker, A. Monteagudo, O. L. Phillips, R. Vásquez-Martínez, et al. 2008. Tree community change across $700 \mathrm{~km}$ of lowland Amazonian forest from the Andean foothills to Brazil. Biotropica 40:525-535. http://dx.doi.org/10.1111/ j.1744-7429.2008.00424.x

Quesada, C., O. Phillips, M. Schwarz, C. Czimczik, T. Baker, S. Patiño, N. Fyllas, M. Hodnett, R. Herrera, S. Almeida, et al. 2012. Basin-wide variations in Amazon forest structure and function are mediated by both soils and climate. Biogeosciences 9:2203-2246. http://dx.doi.org/10.5194/bg-9-2203-2012

Rockwell, C., K. Kainer, C. Staudhammer, and C. Baraloto. 2007. Future crop tree damage in a certified community forest in southwestern amazonia. Forest Ecology and Management 242:108-118. http://dx.doi.org/10.1016/j.foreco.2006.12.028

Rockwell, C., K. Kainer, M. V. N. d'Oliveira, C. Staudhammer, and C. Baraloto. 2014. Logging in bamboo-dominated forests in southwestern Amazonia: caveats and opportunities for smallholder forest management. Forest Ecology and Management 315:202-210. http://dx.doi.org/10.1016/j.foreco.2013.12.022

Salimon, C. I., F. E. Putz, L. Menezes-Filho, A. Anderson, M. Silveira, I. F. Brown, and L. Oliveira. 2011. Estimating state-wide biomass carbon stocks for a REDD plan in Acre, Brazil. Forest Ecology and Management 262:555-560. http://dx.doi.org/10.1016/ j.foreco.2011.04.025

Sasaki, N., and F. E. Putz. 2009. Critical need for new definitions of "forest" and "forest degradation" in global climate change agreements. Conservation Letters 2:226-232. http://dx.doi. org/10.1111/j.1755-263X.2009.00067.X

Schulze, C. H., M. Waltert, P. J. A. Kessler, R. Pitopang, D. Veddeler, M. Mühlenberg, S. R. Gradstein, C. Leuschner, I. Steffan-Dewenter, and T. Tscharntke. 2004. Biodiversity indicator groups of tropical land-use systems: comparing plants, birds, and insects. Ecological Applications 14:1321-1333. http://dx.doi. org/10.1890/02-5409
Schwartzman, S., D. Nepstad, and A. Moreira. 2000. Arguing tropical forest conservation: people versus parks. Conservation Biology 14:1370-1374. http://dx.doi.org/10.1046/j.1523-1739.2000.00227. $\underline{\mathrm{X}}$

Shanley, P., M. da Serra Silva, T. Melo, R. Carmenta, and R. Nasi. 2012. From conflict of use to multiple use: forest management innovations by small holders in Amazonian logging frontiers. Forest Ecology and Management 268:70-80. http://dx.doi. org/10.1016/j.foreco.2011.05.041

Sheil, D., and S. Wunder. 2002. The value of tropical forest to local communities: complications, caveats, and cautions. Conservation Ecology 6:9.

Siikamäki, J., and S. C. Newbold. 2012. Potential biodiversity benefits from international programs to reduce carbon emissions from deforestation. Ambio 41:78-89. http://dx.doi.org/10.1007/ s13280-011-0243-4

Soares-Filho, B. S., D. C. Nepstad, L. M. Curran, G. C. Cerqueira, R. A. Garcia, C. A. Ramos, E. Voll, A. McDonald, P. Lefebvre, and P. Schlesinger. 2006. Modelling conservation in the Amazon basin. Nature 440:520-523. http://dx.doi.org/10.1038/nature04389

Southworth, J., M. Marsik, Y. Qiu, S. Perz, G. Cumming, F. Stevens, K. Rocha, A. Duchelle, and G. Barnes. 2011. Roads as drivers of change: trajectories across the tri-national frontier in MAP, the southwestern Amazon. Remote Sensing 3:1047-1066. http://dx.doi.org/10.3390/rs3051047

Strassburg, B. B. N., A. Kelly, A. Balmford, R. G. Davies, H. K. Gibbs, A. Lovett, L. Miles, C. D. L. Orme, J. Price, R. K. Turner, and A. S. L. Rodrigues. 2010. Global congruence of carbon storage and biodiversity in terrestrial ecosystems. Conservation Letters 3:98-105. http://dx.doi.org/10.1111/j.1755-263X.2009.00092. $\underline{x}$

Strassburg, B. B., A. S. Rodrigues, M. Gusti, A. Balmford, S. Fritz, M. Obersteiner, R. K. Turner, and T. M. Brooks. 2012. Impacts of incentives to reduce emissions from deforestation on global species extinctions. Nature Climate Change 2:350-355. http://dx. doi.org/10.1038/nclimate1375

Sunderlin, W. D., A. Angelsen, B. Belcher, P. Burgers, R. Nasi, L. Santoso, and S. Wunder. 2005. Livelihoods, forests, and conservation in developing countries: an overview. World Development 33:1383-1402. http://dx.doi.org/10.1016/j. worlddev.2004.10.004

Sunderlin, W. D., J. Hatcher, and M. Liddle. 2008. From exclusion to ownership? Challenges and opportunities in advancing forest tenure reform. Rights and Resources Initiative, Washington, D. C., USA.

Sunderlin, W. D., and E. O. Sills. 2012. REDD+ projects as a hybrid of old and new forest conservation approaches. Pages 177-191 in A. Angelsen, M. Brockhaus, W. D. Sunderlin, and L. Verchot, editors. Analysing REDD+: challenges and choices. Center for International Forestry Research, Bogor, Indonesia.

ter Steege, H., N. C. Pitman, D. Sabatier, C. Baraloto, R. P. Salomão, J. E. Guevara, O. L. Phillips, C. V. Castilho, W. E. Magnusson, J.-F. Molino, et al. 2013. Hyperdominance in the Amazonian tree flora. Science 342(6156). http://dx.doi. org/10.1126/science. 1243092 
Thomas, C. D., B. J. Anderson, A. Moilanen, F. Eigenbrod, A. Heinemeyer, T. Quaife, D. B. Roy, S. Gillings, P. R. Armsworth, and K. J. Gaston. 2013. Reconciling biodiversity and carbon conservation. Ecology Letters 16:39-47. http://dx.doi.org/10.1111/ ele. 12054

Tucker, C. M., and M. W. Cadotte. 2013. Unifying measures of biodiversity: understanding when richness and phylogenetic diversity should be congruent. Diversity and Distributions 19:845-854. http://dx.doi.org/10.1111/ddi.12087

United Nations Framework Convention on Climate Change (UNFCCC). 2011. Outcome of the work of the ad hoc working group on long-term cooperative action under the convention (Draft Decision [-/CP.17]). UNFCCC, Bonn, Germany.

Vadjunec, J. M., and D. Rocheleau. 2009. Beyond forest cover: land use and biodiversity in rubber trail forests of the Chico Mendes Extractive Reserve. Ecology and Society 14(2): 29. [online] URL: http://www.ecologyandsociety.org/voll4/iss 2/ $\underline{\operatorname{art} 29 /}$

van der Werf, G. R., D. C. Morton, R. S. DeFries , J. G. J. Olivier, P. S. Kasibhatla, R. B. Jackson, G. J. Collatz, and J. T. Randerson. 2009. $\mathrm{CO}_{2}$ emissions from forest loss. Nature Geoscience 2:737-738. http://dx.doi.org/10.1038/ngeo671

Venter, O., W. F. Laurance, T. Iwamura, K. A. Wilson, R. A. Fuller, H. P. Possingham. 2009. Harnessing carbon payments to protect biodiversity. Science 326:1368. http://dx.doi.org/10.1126/ science. 1180289 